\title{
Synthesis and in vitro antioxidant activity of quinolin-5-ylamine derivatives
}

\author{
L. Mallesha ${ }^{a^{*}}$, B. K. Kendagannaswamy ${ }^{a}$ and K. N. Mohana ${ }^{b}$
}

${ }^{a} P G$ Department of Chemistry, JSS College of Arts, Commerce and Science, Ooty Road, Mysore-25, India

${ }^{b}$ Department of Studies in Chemistry, University of Mysore, Manasagangotri, Mysore 570 006, India

\section{H R O N I C L E}

Article history:

Received January 26, 2013

Received in Revised form

May 20, 2013

Accepted 4 June 2013

Available online

7 June 2013

Keywords:

Quinolin-5-ylamine

Aldehydes

Ketones

Antioxidant

Antioxi
$D P P H$ \begin{abstract}
A B S T R A C T
Imines of six new quinolin-5-ylamine derivatives 3(a-c) and 5(a-c) were synthesized by the reaction of quinolin-5-ylamine (1) with different aldehydes 2 (a-c) and ketones $4(\mathbf{a}-\mathbf{c})$. The chemical structures of the compounds were confirmed by UV-visible, FT-IR and ${ }^{1} \mathrm{H}$ NMR spectral study. New compounds were screened for the antioxidant activity by DPPH (2,2diphenyl-1-picrylhydrazyl) method. Butylated Hydroxytoluene (BHT) was used as standard. All the compounds showed DPPH radical scavenging activity, where compound $\mathbf{3 c}$ was the best radical scavenger.
\end{abstract}

\section{Introduction}

Free radical contains an odd number of electrons which makes it unstable, short lived and highly reactive. Therefore, it reacts quickly with other compounds in order to capture the needed electron to gain stability. Generally, free radical attacks the nearest stable molecule, stealing its electron. When the attacked molecule loses its electron, it becomes a free radical itself, beginning a chain reaction cascade resulting in disruption of a living cell $^{1,2}$. The antioxidants are specifically categorized as natural and synthetic. The natural antioxidants contain a ascorbic acid, phenolic and nitrogen compounds, whereas in synthetic antioxidants it contains phenolic compounds of different alkyl substitution $^{3,4}$. The primary antioxidants comprise essentially sterically hindered phenols and secondary aromatic amines ${ }^{5}$. These antioxidants act usually both through chain transfer and chain termination. The first step of the reactive radical's termination by this type of antioxidants is hydrogen atom transfer from the antioxidant molecule to the reactive radical intermediate ${ }^{6}$. The water soluble antioxidants react with the cell cytosol in which oxidants are present and the lipid soluble

* Corresponding author. Tel: +91-7795101182 E-mail addresses: mallesha83@gmail.com (L.Mallesha) 
antioxidants in the blood plasma protect the cell membranes from lipid peroxidation ${ }^{7}$. The water soluble or lipid soluble compounds are synthesized by the body or obtained through the diet ${ }^{8}$. The amount of protection provided by any antioxidant will depend on its concentration, its reactivity towards the particular reactive oxygen species being considered, and the status of the antioxidants with which it interacts. DPPH is a well-known radical and a scavenger for other radicals.

Schiff bases are used as substrates in the preparation of a number of industrial and biologically active compounds via ring closure, cycloaddition, and replacement reactions ${ }^{9}$. Moreover, Schiff bases are also known to have biological activities such as antimicrobial ${ }^{10-13}$, antifungal ${ }^{14}$, antitumor ${ }^{15-17}$ and herbicides $^{18}$. Quinoline is mainly used as a building block to other specialty chemicals. Its principal use is as a precursor to 8-hydroxyquinoline, which is a versatile chelating agent and precursor to pesticides. The precursors of cyanine dyes are derived from 2- and 4-methyl derivatives by quinoline. Quinoline derivatives are used for functional materials such as fluorescence substances and for medicinal use. It is interesting that above characters change on certain chemical modification. Antioxidant activity of polycyclic pyrimido[4,5-b] quinolines have been reported ${ }^{19}$. Quinolin-5ylamine is a derivative of quinoline and resembles naphthalene. It consists of one benzene ring and pyridine ring fused together. It consists of one benzene ring and pyridine ring fused together. FT-IR and FT-Raman spectral investigations on 4-aminoquinaldine and 5-aminoquinoline have been reported $^{20}$. Synthesis of some 5-aminoquinoline derivatives has been reported ${ }^{21-23}$. In this respect, the present paper reports the synthesis and antioxidant activity of quinolin-5-ylamine derivatives 3(a-c) and $\mathbf{5}(\mathbf{a}-\mathbf{c})$.

\section{Experimental}

\subsection{Materials and Methods}

All solvents and reagents were purchased from Sigma-Aldrich, India. Melting points were determined by Veego melting point VMP III apparatus. Elemental analyses were recorded on VarioMICRO superuser V1.3.2 Elementar. The UV-Visible spectra were recorded on UV-1800 SHIMADZU UV spectrometer with quartz cell of $1.0 \mathrm{~cm}$ path length. The FT-IR spectra were recorded using nujol mull on FT-IR Jasco 4100 infrared spectrophotometer and were quoted in $\mathrm{cm}^{-1}$. ${ }^{1} \mathrm{H}$ NMR spectra was recorded on Bruker DRX -500 spectrometer at $400 \mathrm{MHz}$ using DMSO- $\mathrm{d}_{6}$ as solvent and TMS as an internal standard. Quinolin-5-ylamine was purchased from Sigma-Aldrich, India.

\subsection{General procedure for the synthesis of Schiff bases of quinolin-5-ylamine with different} aldehydes $\mathbf{3}(\boldsymbol{a}-\boldsymbol{c})$

Equimolar concentrations of quinolin-5-ylamine (1, $0.003 \mathrm{~mol})$, aryl aldehydes (2a-c, $0.003 \mathrm{~mol})$ were dissolved in methanol $(20 \mathrm{~mL})$ and 2-3 drops of glacial acetic acid was added to the reaction mixture. It was refluxed for 7-8 h and allowed to stand at room temperature. The progress of the reaction was followed by TLC until the reaction was complete. It was cooled to $0{ }^{\circ} \mathrm{C}$, the precipitate was filtered, washed with diethyl ether and the residue was recrystallized from methanol.

\subsection{1. (6-Bromo-1H-indol-3-ylmethylene)-quinolin-5-yl-amine (3a)}

The product obtained from quinolin-5-ylamine (1) $(0.50 \mathrm{~g}, 0.003 \mathrm{~mol})$ and 6-bromo-1H-indole-3carbaldehyde (2a) $(0.50 \mathrm{~g}, 0.003 \mathrm{~mol})$. FT-IR $\left(\mathrm{KBr}, \mathrm{cm}^{-1}\right) v: 3450(\mathrm{~N}-\mathrm{H}), 3080(\mathrm{Ar} \mathrm{C}-\mathrm{H}), 1610$ $(\mathrm{C}=\mathrm{N}), 1500(\mathrm{C}=\mathrm{C}) .{ }^{1} \mathrm{H}$ NMR $\left(\mathrm{DMSO}_{6}, 400 \mathrm{MHz}\right) \delta: 10.42(\mathrm{~s}, 1 \mathrm{H}, \mathrm{NH}), 8.79(\mathrm{~d}, 1 \mathrm{H}, \mathrm{Ar}-\mathrm{H}), 8.15$ (d, 1H, Ar-H), 8.05 (d, 1H, Ar-H), 7.65 (s, 1H, Ar-H), 7.49 (s, 1H, CH), 7.40 (d, 1H, Ar-H), 7.33 (d, 1H, Ar-H), 7.28 (d, 1H, Ar-H), $7.25(\mathrm{t}, 1 \mathrm{H}, \mathrm{Ar}-\mathrm{H}), 7.20(\mathrm{~s}, 1 \mathrm{H}$, Pyrrole C-H), $6.95(\mathrm{t}, 1 \mathrm{H}, \mathrm{Ar}-\mathrm{H})$. Anal. Calcd.: C-61.73; H-3.45; N-12.00; Found: C-61.91; H-3.62; N-12.24 \%. 


\subsection{2. (2-Nitro-benzylidene)-quinolin-5-yl-amine (3b)}

The product obtained from quinolin-5-ylamine (1) $(0.50 \mathrm{~g}, 0.003 \mathrm{~mol})$ and 2-nitro-benzaldehyde (2b) $(0.52 \mathrm{~g}, 0.003 \mathrm{~mol})$. FT-IR $\left(\mathrm{KBr}, \mathrm{cm}^{-1}\right)$ v: $3094(\mathrm{Ar} \mathrm{C}-\mathrm{H}), 1608(\mathrm{C}=\mathrm{N}), 1600(\mathrm{C}=\mathrm{C}) .{ }^{1} \mathrm{H}$ NMR $\left(\right.$ DMSO$\left.^{-d_{6}}, 400 \mathrm{MHz}\right) \delta: 8.80(\mathrm{~d}, 1 \mathrm{H}, \mathrm{Ar}-\mathrm{H}), 8.60(\mathrm{t}, 1 \mathrm{H}, \mathrm{Ar}-\mathrm{H}), 8.35(\mathrm{~s}, 1 \mathrm{H}, \mathrm{CH}), 8.20(\mathrm{~d}, 1 \mathrm{H}, \mathrm{Ar}-$ $\mathrm{H}), 8.15(\mathrm{~d}, 1 \mathrm{H}, \mathrm{Ar}-\mathrm{H}), 8.00(\mathrm{~d}, 1 \mathrm{H}, \mathrm{Ar}-\mathrm{H}), 7.85(\mathrm{~d}, 1 \mathrm{H}, \mathrm{Ar}-\mathrm{H}), 7.65(\mathrm{t}, 1 \mathrm{H}, \mathrm{Ar}-\mathrm{H}), 7.50(\mathrm{t}, 1 \mathrm{H}, \mathrm{Ar}-$ H), 7.40 (d, 1H, Ar-H), 7.30 (t, 1H, Ar-H). Anal. Calcd.: C-69.31; H-4.00; N-15.15; Found: C-69.24; $\mathrm{H}-4.32 ; \mathrm{N}-15.34 \%$.

\subsubsection{Quinolin-5-yl-(3,4,5-trimethoxy-benzylidene)-amine (3c)}

The product obtained from quinolin-5-ylamine (1) (0.50 g, $0.003 \mathrm{~mol})$ and 3,4,5-trimethoxybenzaldehyde (2c) $(0.68 \mathrm{~g}, 0.003 \mathrm{~mol})$. FT-IR $\left(\mathrm{KBr}, \mathrm{cm}^{-1}\right) v: 3085(\mathrm{Ar} \mathrm{C}-\mathrm{H}), 1604(\mathrm{C}=\mathrm{N}), 1500$ $(\mathrm{C}=\mathrm{C}) .{ }^{1} \mathrm{H}$ NMR $\left(\mathrm{DMSO}_{-} \mathrm{d}_{6}, 400 \mathrm{MHz}\right) \delta: 8.85(\mathrm{~d}, 1 \mathrm{H}, \mathrm{Ar}-\mathrm{H}), 8.45(\mathrm{~s}, 1 \mathrm{H}, \mathrm{CH}), 8.14(\mathrm{~d}, 1 \mathrm{H}, \mathrm{Ar}-\mathrm{H})$, 8.05 (d, 1H, CH), 7.65 (t, 1H, Ar-H), 7.45 (d, 1H, Ar-H), 7.32 (t, 1H, Ar-H), 6.80 (s, 2H, Ar-H), 3.70 (s, 9H, $\mathrm{OCH}_{3}$ ). Anal. Calcd.: C-70.79; H-5.63; N-8.69; Found: C-70.65; H-5.52; N-8.82 \%.

\subsection{General procedure for the synthesis of Schiff bases of quinolin-5-ylamine with different ketones $\mathbf{5}(\boldsymbol{a}-\boldsymbol{c})$}

Equimolar concentrations of quinolin-5-ylamine (1, $0.003 \mathrm{~mol})$, aryl ketones (4a-c, $0.003 \mathrm{~mol})$ were dissolved in methanol $(20 \mathrm{~mL})$ and 2-3 drops of glacial acetic acid was added to the reaction mixture. It was refluxed for 7-8 $\mathrm{h}$ and allowed to stand at room temperature. The progress of the reaction was followed by TLC until the reaction was complete. It was cooled to $0{ }^{\circ} \mathrm{C}$, the precipitate was filtered, washed with diethyl ether and the residue was recrystallized from methanol. New compounds were synthesized by the method summarized in Scheme 1.

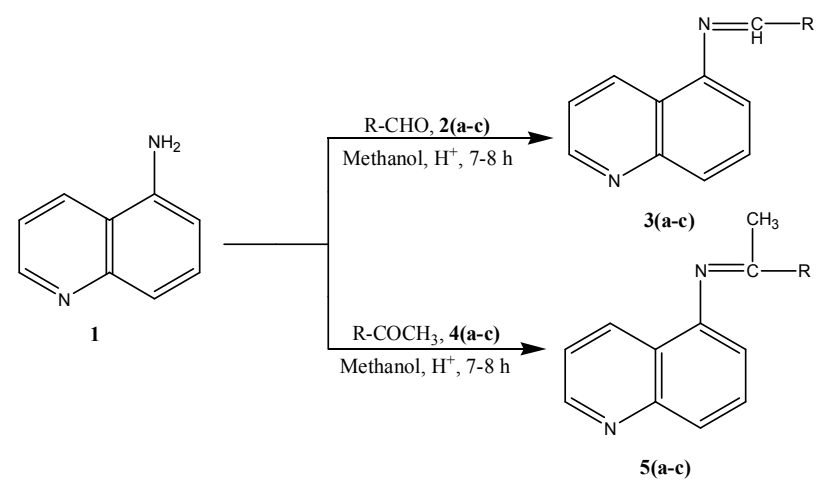

Scheme 1

\subsection{1. (1-Phenyl-ethylidene)-quinolin-5-yl-amine (5a)}

The product obtained from quinolin-5-ylamine (1) $(0.50 \mathrm{~g}, 0.003 \mathrm{~mol})$ and acetophenone (4a) $(0.41 \mathrm{~g}, 0.003 \mathrm{~mol})$. FT-IR $\left(\mathrm{KBr}, \mathrm{cm}^{-1}\right) v: 3080(\mathrm{Ar} \mathrm{C}-\mathrm{H}), 1605(\mathrm{C}=\mathrm{N}), 1510(\mathrm{C}=\mathrm{C}) .{ }^{1} \mathrm{H}$ NMR (DMSO-d $\left.{ }_{6}, 400 \mathrm{MHz}\right) \delta: 8.80(\mathrm{~d}, 1 \mathrm{H}, \mathrm{Ar}-\mathrm{H}), 8.14$ (d, 1H, Ar-H), 8.00 (d, 1H, Ar-H), 7.65 (m, 2H, Ar-H), 7.60 (t, 1H, Ar-H), 7.48 (d, 1H, Ar-H), 7.35 (m, 3H, Ar-H), 7.30 (t, 1H, Ar-H), 0.98 (s, 3H, $\mathrm{CH}_{3}$ ). Anal. Calcd.: C-82.90; H-5.73; N-11.37; Found: C-82.98; H-5.56; N-11.51 \%.

\subsubsection{3-[1-(Quinolin-5-ylimino)-ethyl]-benzonitrile (5b)}

The product obtained from quinolin-5-ylamine (1) $(0.50 \mathrm{~g}, 0.003 \mathrm{~mol})$ and 3-acetylbenzonitrile (4b) $(0.50 \mathrm{~g}, 0.003 \mathrm{~mol})$. FT-IR (KBr, cm $\left.{ }^{-1}\right) v: 3094(\mathrm{Ar} \mathrm{C}-\mathrm{H}), 1608(\mathrm{C}=\mathrm{N}), 1600(\mathrm{C}=\mathrm{C}) .{ }^{1} \mathrm{H}$ NMR $\left(\right.$ DMSO$\left.^{-d_{6}}, 400 \mathrm{MHz}\right) \delta: 8.82(\mathrm{~d}, 1 \mathrm{H}, \mathrm{Ar}-\mathrm{H}), 8.20(\mathrm{~d}, 1 \mathrm{H}, \mathrm{Ar}-\mathrm{H}), 8.15(\mathrm{~d}, 1 \mathrm{H}, \mathrm{Ar}-\mathrm{H}), 7.95(\mathrm{~d}, 1 \mathrm{H}, \mathrm{Ar}-$ H), 7.85 (s, 1H, Ar-H), $7.60(\mathrm{t}, 1 \mathrm{H}, \mathrm{Ar}-\mathrm{H}), 7.55$ (d, 1H, Ar-H), 7.47 (t, 1H, Ar-H), 7.40 (d, 1H, Ar-H), 7.32 (t, 1H, Ar-H), 0.95 (s, 3H, $\mathrm{CH}_{3}$ ). Anal. Calcd.: C-79.68; H-4.83; N-15.49; Found: C-79.49; H$4.64 ; \mathrm{N}-15.56 \%$. 


\subsection{3. (1-Naphthalen-2-yl-ethylidene)-quinolin-5-yl-amine (5c)}

The product obtained from quinolin-5-ylamine (1) $(0.50 \mathrm{~g}, 0.003 \mathrm{~mol})$ and 1-(naphthalen-2yl)ethanone (4c) $(0.59 \mathrm{~g}, 0.003 \mathrm{~mol})$. FT-IR $\left(\mathrm{KBr}, \mathrm{cm}^{-1}\right)$ v: $3080(\mathrm{Ar} \mathrm{C}-\mathrm{H}), 1610(\mathrm{C}=\mathrm{N}), 1505(\mathrm{C}=\mathrm{C})$. ${ }^{1} \mathrm{H}$ NMR (DMSO-d $\left.\mathrm{d}_{6}, 400 \mathrm{MHz}\right) \delta: 8.80(\mathrm{~d}, 1 \mathrm{H}, \mathrm{Ar}-\mathrm{H}), 8.31(\mathrm{~s}, 1 \mathrm{H}, \mathrm{Ar}-\mathrm{H}), 8.10(\mathrm{~d}, 1 \mathrm{H}, \mathrm{Ar}-\mathrm{H}), 8.05$ $(\mathrm{d}, 1 \mathrm{H}, \mathrm{CH}), 7.95(\mathrm{~d}, 1 \mathrm{H}, \mathrm{Ar}-\mathrm{H}), 7.90(\mathrm{~d}, 1 \mathrm{H}, \mathrm{Ar}-\mathrm{H}), 7.62$ (t, 1H, Ar-H), 7.55 (m, 2H, Ar-H), 7.45 (d, 1H, Ar-H), 7.32 (m, 2H, Ar-H), 7.25 (t, 1H, Ar-H), 0.98 (s, 3H, $\left.\mathrm{CH}_{3}\right)$. Anal. Calcd.: C-85.11; H-5.44; N-9.45; Found: C-85.32; H-5.24; N-9.50\%.

\subsection{Antioxidant activity}

The free radical scavenging activity of the synthesized compounds was studied in vitro by 1,1 diphenyl-2-picrylhydrazyl (DPPH) assay method ${ }^{24}$. Stock solution of the drug was diluted to different concentrations (100 and $200 \mu \mathrm{g} / \mathrm{mL}$ ) in methanol. Methanolic solution of the synthesized compounds $(2 \mathrm{~mL})$ was added to $0.003 \%(\mathrm{w} / \mathrm{v})$ methanol solution of DPPH $(1 \mathrm{~mL})$. The mixture was shaken vigorously and allowed to stand for $30 \mathrm{~min}$. Absorbance at $517 \mathrm{~nm}$ was determined and the percentage of scavenging activity was calculated. Ascorbic acid was used as the standard drug. The inhibition ratio (I \%) of the tested compounds was calculated according to the following equation: $I$ $\%=(A c-A s) / A c \times 100$, where $A c$ is the absorbance of the control and $A s$ is the absorbance of the sample. The concentration of compounds providing $50 \%$ scavenging of DPPH $\left(\mathrm{IC}_{50}\right)$ was calculated from the plot of percentage inhibition against concentration $(\mu \mathrm{g} / \mathrm{mL})^{25,26}$.

\section{Results and discussion}

The synthetic route of the compounds is outlined in Scheme 1. The reactions of quinolin-5ylamine with different aldehydes and ketones were carried out in the presence of methanol. The synthesized compounds were characterized by UV-visible, FT-IR and ${ }^{1} \mathrm{H}$ NMR spectral studies. The elemental analyses data showed good agreement between the experimentally determined values and the theoretically calculated values within $\pm 0.4 \%$. The chemical structures and physical data of all the synthesized compounds are given in Table 1 . The electronic absorption spectra of the synthesized compounds showed new bands, and the appearance of longer wavelength absorption band in the UV region confirms the formation of compounds.

The absence of $\mathrm{NH}_{2}$ and $\mathrm{C}=\mathrm{O}$ absorption bands in the IR spectra confirmed that the compounds were synthesized. The appearance of a medium to strong absorption band at around $1600 \mathrm{~cm}^{-1}$ is due to the stretching vibration of $\mathrm{C}=\mathrm{N}$ bond formation in the synthesized compounds. The proton spectral data agree with respect to the number of protons and their chemical shifts with the proposed structures. The proton spectral data of the intermediate, quinolin-5-ylamine (1) shows resonance at $\delta 5.50 \mathrm{ppm}$ $\left(\mathrm{s}, 2 \mathrm{H}, \mathrm{NH}_{2}\right)$. In all the synthesized compounds, the above resonance disappeared.

Table 1. Chemical structures and physical data of the synthesized compounds (3a-c) and 5(a-c)

\begin{tabular}{|c|c|c|c|c|c|c|}
\hline Compound & $\mathrm{R}$ & $\begin{array}{l}\text { Molecular } \\
\text { Formula }\end{array}$ & Mol. Wt. & $\begin{array}{l}\text { Yield } \\
(\%)\end{array}$ & $\begin{array}{l}\text { M.R. } \\
\left({ }^{\circ} \mathrm{C}\right)\end{array}$ & $\begin{array}{l}\text { UV-visible } \\
(\mathrm{nm})\end{array}$ \\
\hline $3 \mathbf{a}$ & & $\mathrm{C}_{18} \mathrm{H}_{12} \mathrm{BrN}_{3}$ & 349.02 & 65.4 & $82-84$ & 380 \\
\hline $3 \mathbf{b}$ & & $\mathrm{C}_{16} \mathrm{H}_{11} \mathrm{~N}_{3} \mathrm{O}_{2}$ & 277.3 & 62.0 & $118-122$ & 285 \\
\hline $3 c$ & & $\mathrm{C}_{19} \mathrm{H}_{18} \mathrm{~N}_{2} \mathrm{O}_{3}$ & 278.3 & 68.4 & $88-90$ & 252 \\
\hline
\end{tabular}




5a

DPPH is a well-known radical and a scavenger for other radicals. DPPH has two major applications in laboratory research: (a) to monitor the chemical reactions involving radicals. (b) The number of initial radicals can be counted from the change in the optical absorption at $520 \mathrm{~nm}$ or in the electron paramagnetic resonance signal of the DPPH. The in vitro scavenging assay of DPPH radicals was performed spectrophotometrically with BHT as positive control. Percentages of DPPH radical scavenging activity were tabulated in Table 2. All the compounds showed antioxidant activity (Fig. 1). The percentage scavenging effect of the compound 3c at $200 \mu \mathrm{g} / \mathrm{mL}$ is $58.0 \%$. Compounds 3a, $\mathbf{3 b}, \mathbf{5 a}, \mathbf{5 b}$ and $\mathbf{5 c}$ showed weak activity. The compound 3c showed higher radical inhibition activity due to the presence of methoxy group (electron donating group) in the aromatic ring.

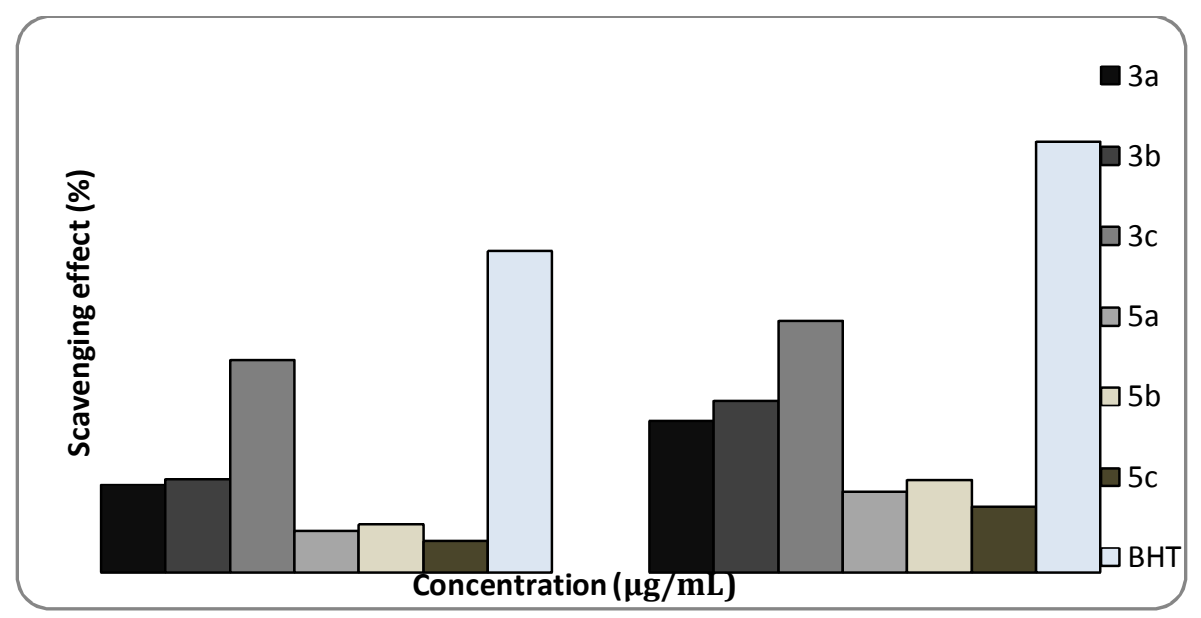

Fig. 1.

Table 2 DPPH radical scavenging activity of the tested compounds

\begin{tabular}{lll}
\hline Compound & \multicolumn{2}{l}{ Scavenging effect $(\%)$} \\
\cline { 2 - 3 } & \multicolumn{2}{l}{ Concentration of the tested compounds $(\mu \mathrm{g} / \mathrm{mL})$} \\
& 100 & 200 \\
\hline $\mathbf{3 a}$ & 20.2 & 34.9 \\
$\mathbf{3 b}$ & 21.4 & 39.5 \\
$\mathbf{3 c}$ & 49.0 & 58.0 \\
$\mathbf{5 a}$ & 09.6 & 18.5 \\
$\mathbf{5 b}$ & 11.0 & 21.3 \\
$\mathbf{5 c}$ & 07.2 & 15.2 \\
BHT & 74.1 & 99.3 \\
\hline
\end{tabular}

\section{Conclusion}

In conclusion, a series of new quinolin-5-ylamine derivatives 3(a-c) and 5(a-c) were synthesized in good yield, characterized by different spectral studies and their antioxidant activity have been evaluated. All the compounds showed DPPH radical scavenging activity, where compound $\mathbf{3 c}$ was the best radical scavenger. 


\section{Acknowledgements}

One of the authors (LM) grateful to JSS College of Arts, Commerce and Science, Mysore, to carryout antioxidant activity.

\section{References}

1. Cheeseman K. H., and Slater, T. F. (1993) Free radical in medicine, Churchill Livingstone, New York.

2. Mitchell R. N., and Cotran R. S. (2003) Basic Pathology, $7^{\text {th }}$ Ed., Harcourt Pvt. Ltd., New Delhi, p. 3.

3. Hall C. A., and Cuppett S. L. (1997) In Antioxidant Methodology: In Vivo and In Vitro Concepts, AOCS Press, Champaign, IL, p. 2.

4. Hudson B. J. F. (1990) Food Antioxidants, Elsevier Applied Science, London,.

5. Gugumus F. (1990) Oxidation Inhibition in Organic Materials, Vol. 1, CRC Press, Boca Raton, USA.

6. Pospisil J., Horak J., Pilar J., Billingham N. C., Zweifel H., and Nespurek S. (2003) Influence of testing conditions on the performance and durability of polymer stabilisers in thermal oxidation. Polym. Degrad. Stab., 82, 145-162.

7. Sies H. (1997) Oxidative stress: oxidants and antioxidants. Exp. Physiol., 82, 291-295.

8. Vertuani S., Angusti A., and Manfredini S. (2004) The antioxidants and pro-antioxidants network: an overview. Curr. Pharm. Des., 10, 1677-1694.

9. Karia F. D., and Parsania P.H. (1999) Synthesis, biological and thermal properties of Schiff bases of bisphenol-C. Asian J. Chem., 11, 991-995.

10. More P. G., Bhalvankar R. B., and Pattar S. C. (2001) Synthesis and biological activities of Schiff bases of aminothiazoles. J. Indian Chem. Soc., 78, 474-475.

11. El-Masry A. H., Fahmy H. H., and Abdelwahed S. H. A. (2000) Synthesis and antimicrobial activity of some new benzimidazole derivatives. Molecules, 5, 1429-1438.

12. Baseer M. A., Jadhav V. D, Phule R. M., Archana Y. V., and Vibhute Y. B. (2000) Synthesis and antimicrobial activity of some new Schiff bases. Orient. J. Chem., 16, 553-556.

13. Pandeya S. N., Sriram D., Nath G., and De Clercq E. (1999) Synthesis and antimicrobial activity of Schiff and Mannich bases of isatin and its derivatives with pyrimidine. IL Farmaco, 54, 624-628.

14. Singh W. M., and Dash B. C. (1988) Synthesis of some new Schiff bases containing thiazole and oxazole nuclei and their fungicidal activity. Pesticides, 22, 33-37.

15. Hodnett E. M., and Dunn W. J. (1970) Structure-antitumor activity correlation of some Schiff bases, $J$. Med. Chem., 13, 768-770.

16. Desai S. B., Desai P. B., and Desai K. R. (2001) Synthesis of some Schiff bases, thiazolidones, and azetidinones derived from 2,6-diaminobenzo[1,2-d:4,5- $\left.d^{\prime}\right]$ bisthiazole and their anticancer activities. Heterocycl. Commun., 7, 83-90.

17. Pathak P., Jolly V. S., and Sharma K. P. (2000) Synthesis and biological activities of some new substituted arylazo Schiff bases, Oriental. J. Chem., 16, 161-162.

18. Samadhiya S., and Halve A. (2001) Synthetic utility of Schiff bases as potential herbicidal agents, Orient. J. Chem., 17, 119-122.

19. El-Gazzar A. B. A., Hafez H. N., Abu-Hashem A. A., and Aly A. S. (2009) Phosphorus, Sulfur, and Silicon and the Related Elements, 184, 379-405.

20. Puviarasan N., Arjunan V., and Mohan S. (2004) FTIR and FT-Raman Spectral Investigations on 4Aminoquinaldine and 5-Aminoquinoline. Turk. J. Chem., 28, 53-65.

21. Stupnikova T. V. et al., (1982) Synthesis and reactions of quinolylindoles with an azomethine bridge between the ring systems. Dopovidi Akademii Nauk Ukrainskoi RSR Seriya B-Geologichni Khimichni Ta Biologichni Nauki, 7, 57-59.

22. Ignatovich Zh. V., Kadutskii A. P., Koroleva E. V., Baranovskii A. V., and Gusak K. N. (2009) Reduction transformations of Schiff bases in the synthesis of functionally substituted heteroaromatic amines. Russ. J. Org. Chem., 45, 1070-1078.

23. Mohana K. N., Mallesha L., and Gurudatta D. M. (2011) Synthesis and antimicrobial activity of 5aminoquinoline and 3-amino phenol derivatives. Inter. J. Drug Design and Discovery, 2, 584-590.

24. Shih M. H., and Ke F. Y. (2004) Synthesis and evaluation of antioxidant activity of sydnonyl substituted thiazolidinone and thiazoline derivatives. Bioorg. Med. Chem., 12:4633-4643.

25. Gulcin I., Beydemir S., Alici H. A., Elmastas M., and Buyukokuroglu M. E. (2004) In vitro antioxidant properties of morphine. Pharmacol Res., 49:59-66.

26. Elmastas M., Gulcin I., Beydemir S., Kufreviogluo, and Aboul-Enein H. Y. (2006) A study on the in vitro antioxidant activity of juniper seeds extracts. Anal. Lett., 39:47-65. 